Article

\title{
InSAR Time Series Analysis of Natural and Anthropogenic Coastal Plain Subsidence: The Case of Sibari (Southern Italy)
}

\author{
Giuseppe Cianflone ${ }^{1, *}$, Cristiano Tolomei ${ }^{2}$, Carlo Alberto Brunori ${ }^{2}$ and Rocco Dominici ${ }^{1}$ \\ Received: 25 August 2015; Accepted: 17 November 2015; Published: 30 November 2015 \\ Academic Editors: Roberto Tomas, Richard Gloaguen and Prasad S. Thenkabail \\ 1 Department of Biology, Ecology and Earth Sciences, University of Calabria, Via P. Bucci, cubo 15B, \\ 87036 Arcavacata di Rende (Cs), Italy; rocco.dominici@unical.it \\ 2 Istituto Nazionale di Geofisica e Vulcanologia (INGV), Via di Vigna Murata, 605, 00143 Rome, Italy; \\ cristiano.tolomei@ingv.it (C.T.); carloalberto.brunori@ingv.it (C.A.B.) \\ * correspondence: giuseppe.cianflone@unical.it; Tel.: +39-338-615-5605
}

\begin{abstract}
We applied the Small Baseline Subset multi-temporal InSAR technique (SBAS) to two SAR datasets acquired from 2003 up to 2013 by Envisat (ESA, European Space Agency) and COSMO-SkyMed (ASI, Italian Space Agency) satellites to investigate spatial and temporal patterns of land subsidence in the Sibari Plain (Southern Italy). Subsidence processes (up to $\sim 20 \mathrm{~mm} / \mathrm{yr}$ ) were investigated comparing geological, hydrogeological, and land use information with interferometric results. We suppose a correlation between subsidence and thickness of the Plio-Quaternary succession suggesting an active role of the isostatic compensation. Furthermore, the active back thrusting in the Corigliano Gulf could trigger a flexural subsidence mechanism even if fault activity and earthquakes do not seem play a role in the present subsidence. In this context, the compaction of Holocene deposits contributes to ground deformation. Despite the rapid urbanization of the area in the last 50 years, we do not consider the intensive groundwater pumping and related water table drop as the main triggering cause of subsidence phenomena, in disagreement with some previous publications. Our interpretation for the deformation fields related to natural and anthropogenic factors would be a comprehensive and exhaustive justification to the complexity of subsidence processes in the Sibari Plain.
\end{abstract}

Keywords: SBAS-InSAR; Sibari Plain; subsidence; geology; anthropic processes

\section{Introduction}

Many coastal and delta plains worldwide are affected by land subsidence phenomena [1,2], which often involve inhabited areas causing conspicuous economic costs.

Examples come from different geodynamic, geological, climatic and social contexts. In Italy, subsidence due to a combination of natural causes and anthropogenic activities is observed in the Venice coastland and the Po delta plain [3-6], while in the United States in correspondence of the coastal areas of Southern Louisiana and Mississippi [7-11]. Other examples are observed in the Yellow River and Yangtze China Deltas [12,13], along the Taiwan coastland [14-16], in the Indonesian Semerang city [17], in Thessaloniki coastal plain and municipality region (Northern Greece) [18,19].

Over the last decades, the land subsidence monitoring has been significantly improved thanks to the earth observation techniques based on Interferometric Synthetic Aperture Radar (InSAR). Furthermore, the recent advances in radar satellite capabilities and techniques based on the interferometric analysis of large datasets [20-29] have allowed even better spatial and temporal resolutions. 
We applied multitemporal differential SAR Interferometry technique and specifically the Small Baselines Subset (SBAS) approach [20] to investigate the ground deformations of the Sibari Plain (SP), located in the northeastern sector of the Calabria Region (Southern Italy) covering an area of $\sim 500 \mathrm{~km}^{2}$. This Plain involves an important economic weight due to the agricultural production and a cultural appeal related to the presence of the ancient Sybaris, a powerful Greek colony in Magna Grecia founded in $720 \mathrm{BC}$. The area is also susceptible to flooding risk, reduced by means of a drainage channels network.

The used SAR datasets cover the temporal interval spanning from May 2003 and September 2013 for both ascending and descending orbits acquired by Envisat and COSMO-SkyMed satellites (for details see Table 1). Envisat is a European Space Agency (ESA) satellite operating in the C-Band (5.6 cm of wavelength) launched in the 2002 and operating up to 2012, with a revisiting period of 35 days, covering an area of about $100 \times 100 \mathrm{~km}$. The COSMO-SkyMed mission consists of a constellation from the Agenzia Spaziale Italiana (ASI) in the X-Band frequency $(3.2 \mathrm{~cm}$ of wavelength). The first satellite of the constellation has been launched in June 2007 and the constellation (four satellites) has been fully operative by the end of 2010. The used acquisitions (Himage mode) are characterized by a swath of about $40 \times 40 \mathrm{~km}^{2}$ with a revisiting time period of 16 days.

Table 1. Used image datasets. Ground resolution values are obtained after a multi-looked operation.

\begin{tabular}{cccccccc}
\hline Satellite & Orbit Type & Track/Beam & $\begin{array}{c}\text { No. of Used } \\
\text { Images }\end{array}$ & $\begin{array}{c}\text { No. of } \\
\text { Pairs }\end{array}$ & Temporal Span & $\begin{array}{c}\text { Ground } \\
\text { Resolution (m) }\end{array}$ & $\begin{array}{c}\text { Incidence } \\
\text { Angle }\end{array}$ \\
\hline Envisat & Ascending & 86 & 38 & 137 & $\begin{array}{c}\text { 4 May 2003 to } \\
\text { 19 September 2010 }\end{array}$ & 90 \\
Envisat & Descending & 222 & 33 & 115 & $\begin{array}{c}\text { 27 August 2003 to } \\
\text { 25 August 2010 }\end{array}$ & 90 \\
COSMO-SkyMed & Ascending & B12 & 12 & 25 & $\begin{array}{c}\text { 5 December 2012 to } \\
\text { 19 July 2013 }\end{array}$ & 25 \\
COSMO-SkyMed & Descending & B03 & 33 & 60 & $\begin{array}{c}\text { 29 October 2009 to } \\
\text { 2 October 2010 }\end{array}$ & 25 \\
\hline
\end{tabular}

Moreover, the availability of ascending and descending datasets allowed us to discriminate the vertical and east-west displacement components.

Finally, the retrieved InSAR results were validated by means of GPS measurements then analyzed and interpreted considering the available geological and hydrogeological information as well as new data collected during our field surveys.

\section{Geological Setting}

The SP is located along the boundary between Calabrian Arc and Southern Apennines (Figure 1), with the Pollino massif to the north and Sila massif to the south. The Calabrian Arc represents a fault-bounded continental fragment within the western Mediterranean orogeny. The tectonic evolution is related to the subduction and rollback of Ionian oceanic lithosphere and the slow convergence between the Eurasian and African-Adriatic continental plates [30-32]. The Southern Apennines are a NW-SE oriented segment of the Apennines thrust belt. It is characterized by a duplex structure, which consists of two thrusts belts overlapping the Apulian platform [33-36].

In the SP, the chain is prevalently composed by Apenninic terranes overlapped by thin Calabrian Arc units [37]. The first ones, outcropping along the northwestern side of the SP, are made by Mesozoic-Tertiary carbonatic succession and "flyschiod" deposits overlapped by Plio-Pleistocene siliciclastic succession [38-40]. Instead, the Calabrian Arc terranes, cropping out along the southern margin, consist of igneous and metamorphic rocks [41] (Figure 1).

In the central sector of the SP, the basement is overlapped by a thick Miocene-Holocene succession; the mio-pliocenic deposits represent the infilling of the Sibari-Corigliano Basin, which evolution is strictly connected with the Sangineto Line activity [42,43], and they are deformed by fault activity with formation of morphological/structural highs and lows [44]. In [45], the authors 
suggest the existence of WNW-ESE trending shallow-crustal folds, developed within a recent and still active transpressional field.

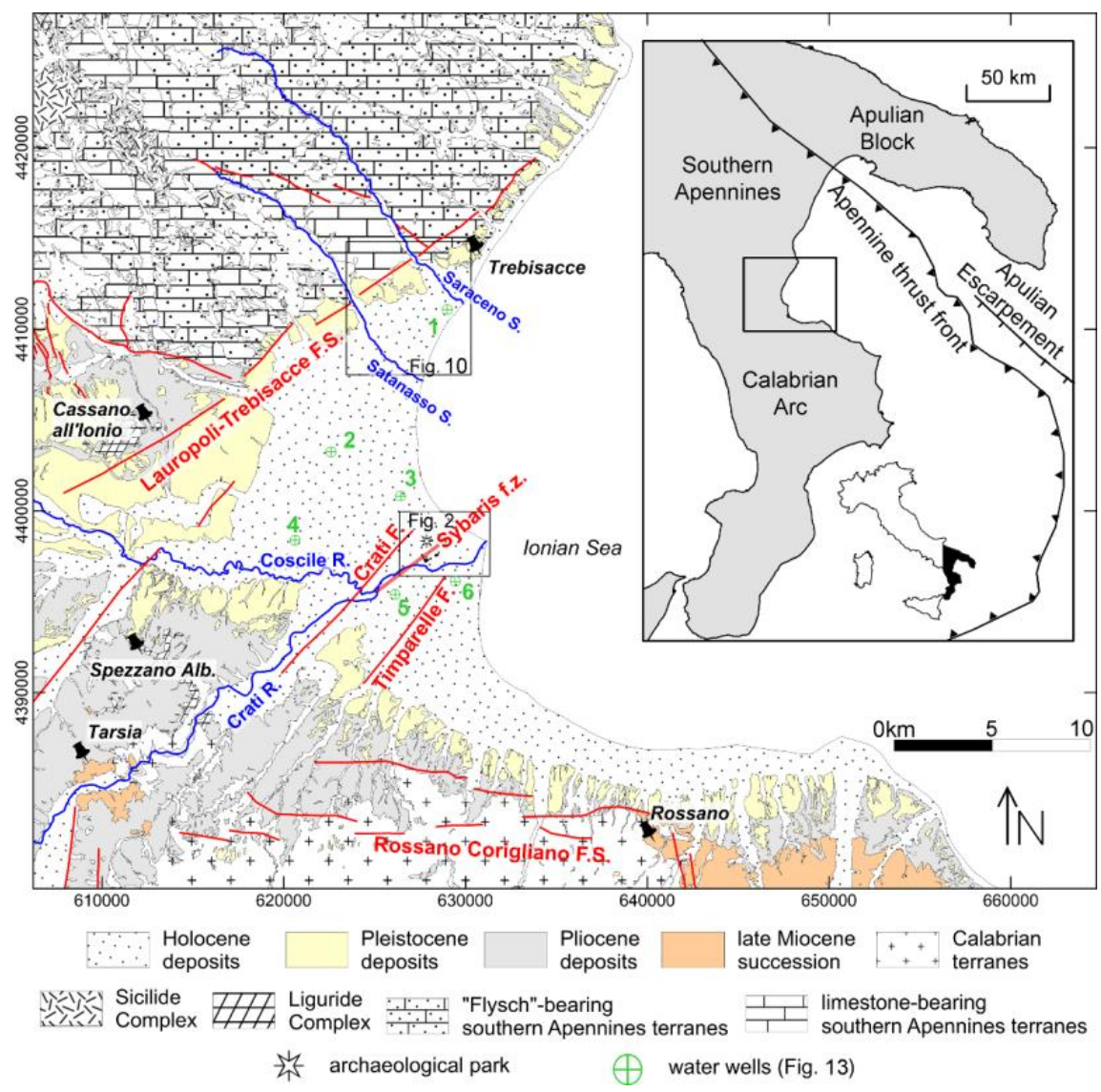

Figure 1. Simplified lithological map of the study area with projection of the faults of ITaly HAzard from CApable faults database [46] and of the Sybaris fault zone (f.z.) [47].

The boundaries between the SP and Pollino and Sila massifs are marked by dislocations produced along plio-holocenic high angle faults. The latter is represented in the NW sector by the NW-SE normal fault of the Sangineto Line [48,49], while in correspondence of the Sila Massif it consists of the WNW-ESE Rossano-Corigliano fault (Figure 1). The recent activity of these faults is still debated [49-53].

The existence of NE-SW trending normal fault in the area of the Crati Delta is suggested by [48]; recent coseismic evidences related to a NE-SW structural lineament, maybe active during the period between the II and the VII-IX century A.D., are observed in Parco del Cavallo and Casa Bianca archaeological sites [47].

Five to eleven different order of marine terraces are recognized along the outer limit of the plain and uplift rates greater than $3.5 \mathrm{~mm} / \mathrm{yr}$ are estimated [50,54,55].

Holocene deposits are the result of the post Last Glacial Maximum (LGM) transgression and the following (started about 6 ka B.P.) normal regression related to the Crati Delta progradation [56,57]. The Holocene evolution occurred in a tectonic-controlled setting, which drives the thickness and the facies association lateral variability of the deposits [57]. The post LGM succession consists of marine clayey-silty deposits, overlapping a late Pleistocene coarse-grained unit, passing upward to costal, deltaic and continental ones [57-59].

In the Northern sector, the main geomorphological elements are the alluvial fans of Raganello River, Satanasso Fiumara and Saraceno Fiumara. 


\section{Historical Subsidence}

Subsidence is a well-known phenomenon in the Sybaris archaeological area (Figure 2), testified by the presence of three overlapping ancient towns, the Greek Sybaris (720-510 BC), the Hellenistic Thurii (444-203 BC) and the Roman Copiae (193 BC), presently buried between 7 and $3.5 \mathrm{~m}$ [60].

In [61], the author calculates subsidence rates $\geqslant 0.57 \mathrm{~mm} / \mathrm{yr}(2330-860 \mathrm{ka}$ B.P.) and $\geqslant 4.31 \mathrm{~mm} / \mathrm{yr}$ (860 ka B.P.-present) for Casa Bianca, $\geqslant 0.35 \mathrm{~mm} / \mathrm{yr}$ (2660-1600 ka B.P.) and $\geqslant 2.05 \mathrm{~mm} / \mathrm{yr}$ (1600 ka B.P.-present) for Parco del Cavallo, $\geqslant 0.4 \mathrm{~mm} / \mathrm{yr}$ for Stombi.

The subsidence in the archaeological area starts in the late Pleistocene up to the Holocene and is due by a combination of causes as neotectonic activity, glacio-eustatic variations and sediments compaction [62-64]. In the archaeological area the subsidence variability is correlated to the lateral variation of facies [65] and the most of geotechnical subsidence can be ascribed to a very compressible clay layer, laterally discontinuous, between 35 and $40 \mathrm{~m}$ of depth [62,65]. Since the 1950s, $20 \mathrm{~cm}$ of subsidence have been recorded and ascribed to groundwater exploitation and related primary consolidation $[65,66]$. The subsidence in the Casa Bianca and Parco del Cavallo sites is confirmed by [67], which instead calculates a mean uplift rate of $\sim 0.5 \mathrm{~mm} / \mathrm{yr}$ in the last $11.2 \mathrm{ka}$ for the Stombi site and hypothesizes that subsidence started 4ka B.P. and is ascribed to the deposition of fine compressible sediments, so excluding the tectonic contribution. The author of [68] highlights a temporal variability for the mean subsidence rates showing a peak of $\sim 5-6 \mathrm{~mm} / \mathrm{yr}$ in the Early Holocene whilst stability or small uplift in historical age ( 3-1.3 ka B.P.) for the Casa Bianca and Parco del Cavallo sites, no subsidence in the Stombi site and uplift $(\sim 1.5 \mathrm{~mm} / \mathrm{yr}) 6 \mathrm{~km}$ toward SE from archaeological area; this differential subsidence is mainly controlled by local tectonic structures.

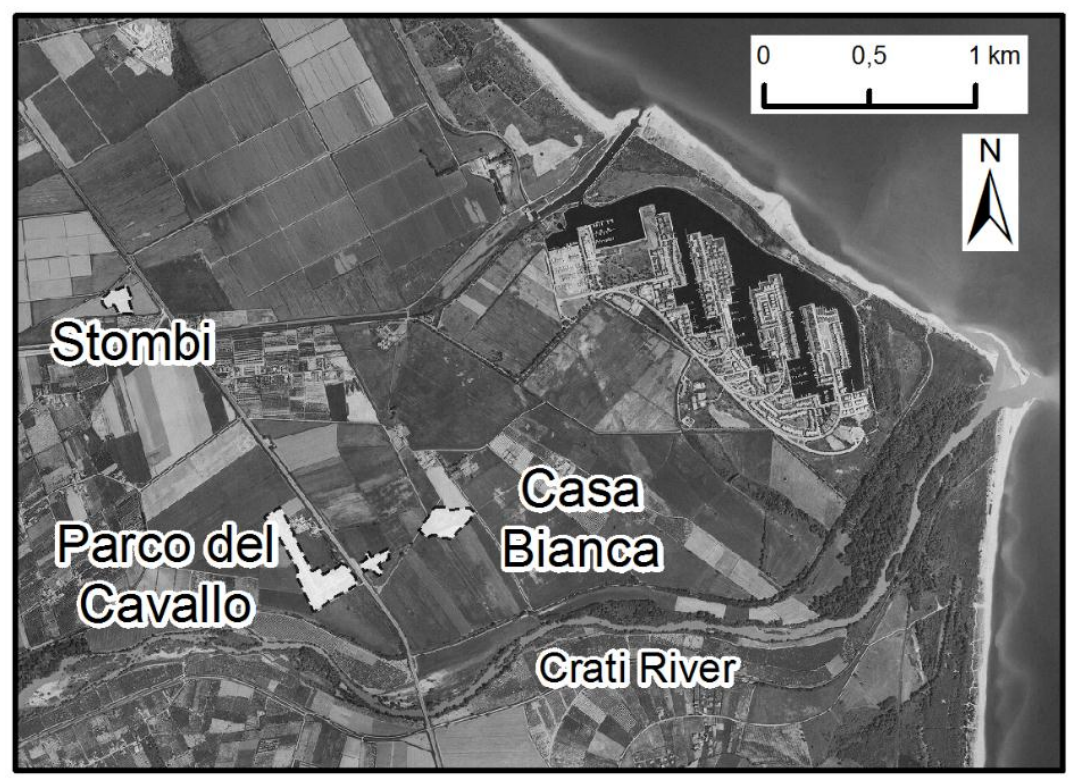

Figure 2. The archaeological sites of the ancient Sybaris (see inset in Figure 1 for its location).

\section{InSAR Adopted Tecnique}

The classical differential SAR Interferometry (InSAR) is a technique that allows us to estimate the ground surface movements occurred between two different passes of the satellite over the same area using Synthetic Aperture Radar (SAR) data. The phase difference at each pixel is calculated after proper image co-registration resulting in a new image, called interferogram, an interference pattern made up of fringes [69]. Each fringe represents a ground movement along the sensor line of sight (LOS) equal to $\lambda / 2$ (where $\lambda$ is the adopted radar wavelength). 
There are many physical phenomena contributing to phase measurements: phase variations within a pixel, the contribution of orbital variations, topography, atmosphere, and displacement. These contributions are estimated and then removed so to obtain only the effective ground displacement.

Our goal is to investigate the temporal evolution of the detected deformations. To this aim several different approaches have been proposed in the last decade to generate time series of ground displacement, capable of measuring the ground velocities rates with accuracies of $\sim 1 \mathrm{~mm} / \mathrm{yr}$ [70]. In this work, we applied the Small Baseline Subset InSAR technique (SBAS; [20]). The used SAR images were coupled based on constraints of small temporal and spatial baselines. The SBAS algorithm combines these acquisitions, also included in different interferometric subsets, using a minimum norm criteria combination of the velocity deformation, based on the Singular Value Decomposition (SVD) method. During the SBAS processing the estimation and removal of temporally decorrelated atmospheric artefacts are performed using double-pass filtering in the temporal and spatial domains, as explained in [20]. Moreover, we used the SRTM DEM (90-m resolution) for the subtraction of topography phase (http://www2.jpl. nasa.gov/srtm). Once the displacement time series is retrieved, the mean ground velocity in the time period covered by the data was calculated.

In detail, we applied the SBAS technique to four image datasets, two acquired from the European Space Agency (ESA) Envisat sensor and two from the Italian Space Agency (ASI) COSMO-SkyMed satellites. The first group contains 32 Envisat images acquired on the descending orbit (track 222, frame 2803), in the period 2004-2010 imposing 700 days as maximum temporal baseline and 350 meters for the maximum perpendicular one and considering 100 pairs. Instead, the ascending dataset (track 86, frame 789) is formed by 38 ASAR images acquired in the period 2003-2010 setting 900 days for the maximum temporal baseline and 350 meters for the maximum spatial one resulting in 135 interferograms. The second group (COSMO-SkyMed data) was composed of 28 images from the ascending orbit considering 180 days for the maximum temporal baseline and 700 meters as maximum spatial baseline resulting in 137 interferograms, spanning the interval 2011-2013 and 12 images from the descending orbit, acquired in the interval 2011-2012 setting 100 days for the temporal and 1000 meters for the spatial maximum baselines respectively forming 47 interferograms. We used the Sarscape software (Sarmap, $\mathrm{CH}$ ) applying a looking factors equal to 20 and 4 for the azimuth and range direction, respectively for the ascending and descending Envisat processing obtaining a ground resolution of 80 meters and 11, 12 for the COSMO-SkyMed case with a final ground posting of 25 meters; later downgraded to 100 meters for the post-processing analysis. The initial performed multi-looking operation reduced the image radar noise (speckle) and increased the signal to noise ratio.

During the processing the precise orbital files (Envisat case) were used to estimate and remove orbital errors and Ground Control Points (GCPs) were selected, especially along the frame borders (in slant range geometry) and possibly over stable areas, to remove residual ramps. A stable point (under the geological point of view) was chosen as reference point (red star) for the retrieved mean ground velocity maps (Figure 3).

Initially, we validated our results comparing the ascending and descending velocity map after shifting the former with respect to the reference point of the latter preventing the subsidence areas. We also validated the Envisat results comparing with the available GPS in the whole SAR frames (Figure 3). Firstly, we projected the GPS velocities onto the ascending and descending SAR LOS respectively then we averaged the InSAR velocities in correspondence of the GPS benchmarks considering a buffer area of 200 meters. The comparison between GPS and InSAR velocities is shown in Figure $3 \mathrm{a}, \mathrm{b}$ for the ascending and descending tracks. Except for very few GPS benchmarks, the velocities differences are within $1.5 \mathrm{~mm} / \mathrm{yr}$, which is the associated error to the multi-temporal SAR outputs. Unfortunately, it has not been possible to perform the same validation method for the CSK results because not enough CGPS are available. However, considering the common similar patterns and trends for both Envisat and CSK ascending and descending retrieved maps, we convinced the 
good quality of the obtained CSK results. Note that for the CSK processing we focused our study on the Sibari Plain.

To this aim, we calculated the East $(E)$ and Vertical $(V)$ component solving the following system of equation:

$$
\begin{gathered}
E=((u 2 d / \text { det }) \times(A s c-(n 2 a) \times N)))-((u 2 a / \text { det }) \times(D s c-(n 2 d \times N))) \\
V=((-e 2 a / \text { det }) \times(A s c-(n 2 a) \times N)))+((e 2 a / \text { det }) \times(D s c-(n 2 d \times N))) \\
\text { where det }=((e 2 d \times u 2 d)-(u 2 a \times e 2 d)
\end{gathered}
$$

where $u 2 d, e 2 d, n 2 d, u 2 a, e 2 a$ and $n 2 a$ are the descending and ascending cosine directors respectively, and Asc and Dsc are the ascending and descending mean velocity maps.
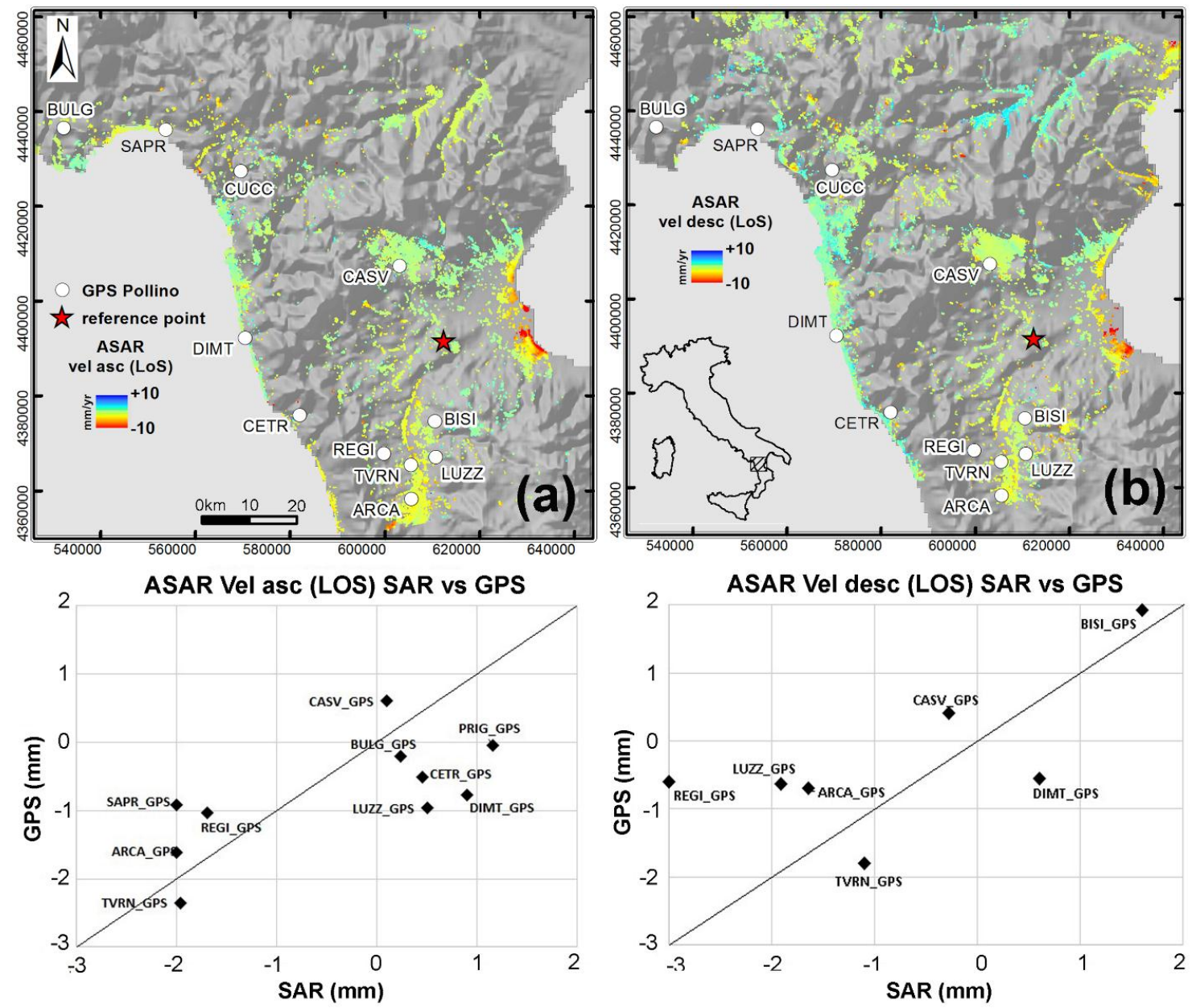

Figure 3. (a) Ascending and (b) descending line of sight (LOS) ground velocity maps. Red star represents the stable point (stable means that the mean velocity is $0 \mathrm{~mm} / \mathrm{yr}$ ) used as reference point. In the maps are also plotted the GPS benchmarks used during the validation of the Envisat results. The diagrams show the comparison between the LOS Synthetic Aperture Radar (SAR) velocities and GPS. The correlation coefficient is respectively 0.51 and 0.65 for the ascending and descending cases, while the mean squared error is $1.1 \mathrm{~mm}$ and $1.2 \mathrm{~mm}$.

Concerning the third condition, we imposed the North equal to the interpolated CGPS one. The final Vertical and East component (Figure 4) result quite sparse, this mainly depends on the difficulty to obtain a large coverage for the ascending and descending velocity maps due to the land cover 
and agricultural use of the investigated area leading to a fast coherence loss. Moreover, about the East component some overestimated values are present in the North Eastern part probably due to unwrapping errors due to the presence of the mountains.

We performed the previous post-processing steps for the full SAR frames and only at a later stage; we focused our analysis and interpretations referring to the East and Vertical component about the Sibari Plain area.
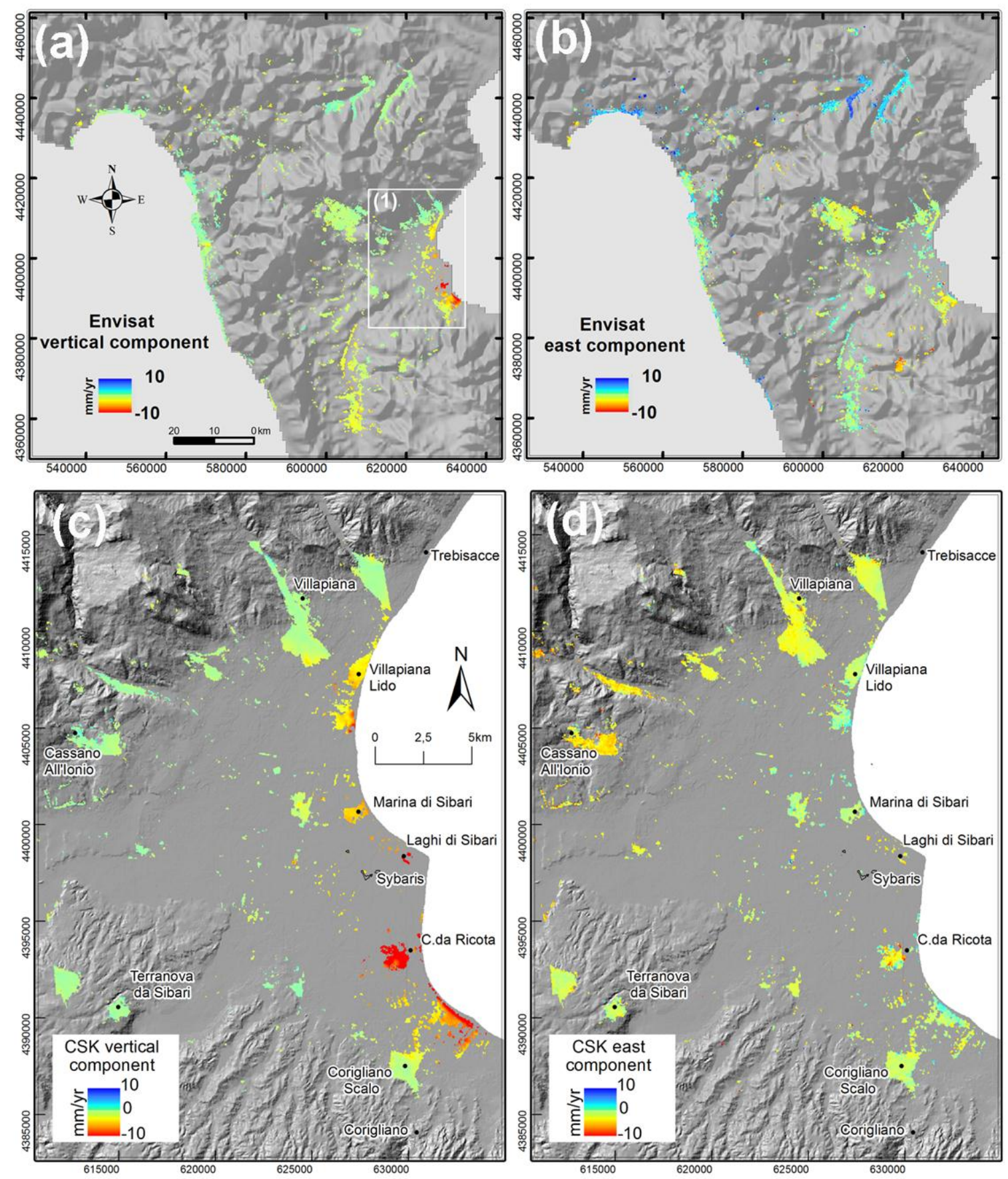

Figure 4. Mean deformation velocity components computed from $(\mathbf{a}, \mathbf{b})$ Envisat and $(\mathbf{b}, \mathbf{c})$ COSMO-SkyMed dataset. (a,c) Vertical velocity component; positive values indicate uplift and negative values subsidence. (b,d) East component; positive values indicate eastward displacement and negative values indicate westward displacement. The area covered by COSMO-SkyMed data is represented by inset (1) in the panel a. 


\section{InSAR Results}

In the following, we report the deformation pattern of SP at a large scale retrieved by InSAR processing and discuss the results in detail using available tectonic, stratigraphic, geomorphological and hydrogeological information. We investigate natural and/or human causes of the vertical and horizontal surface displacements.

The distribution of Vertical component shows a coastal area (from Villapiana Lido to Marina di Schiavonea) characterized by subsidence with velocity up to $\sim-20 \mathrm{~mm} / \mathrm{yr}$ (Envisat and COSMO-SkyMed sensors); on the contrary, boundary areas of SP show $\sim 0 \mathrm{~mm} / \mathrm{yr}$ on the vertical velocity component (Figure 4).

The horizontal Eat-West component shows low displacement values that are inside the errors range and are not significant.

In the archaeological area, the subsidence rate is $\sim 2 \mathrm{~mm} / \mathrm{yr}$ (Envisat) and $\sim 3 \mathrm{~mm} / \mathrm{yr}$ (COSMO-SkyMed) for the Parco del Cavallo site and $\sim 2 \mathrm{~mm} / \mathrm{yr}$ (Envisat) for the Casa Bianca site. These values are comparable to the velocities calculated by previous authors [61,67].

\section{Discussion}

We analyzed different causes contributing to subsidence phenomena. To this aim, we compared the InSAR results in time and space with the geodynamic and structural settings, the seismicity distribution, the spatial variation of the Plio-Quaternary and Holocene deposits successions thickness and compaction, depth variation of the water table and urban sprawl.

\subsection{Geodynamic Setting}

The SP is located at the junction of the Calabrian Arc and the Southern Apennine. Moving few kilometers towards SE from the SP, the geodynamic setting is complicated by the presence of the junction (Apulia Escarpment) (Figure 1) between the thin Ionian basin crust (southward) and the thick crust of the Apulian platform (northward). In the Ionian Sea, in front of the SP an active oblique-contractional belt (the Amendolara Ridge) is recognized. The latter is due to the combined effects of subduction retreat of the Ionian slab underneath Calabria and stalling of Adriatic slab retreat underneath the Apennines [71]. The belt consists of the alignment of three anticlines (Amendolara, Rossano and Cariati) bounded by a main SW-verging back-thrust (Figure 5a).

A flexural subsidence, probably triggered by a back-thrusting [72], is considered one of the mechanisms to explain the ground subsidence detected by InSAR results along coastal sector of the SP (Figure 5b).

\subsection{Structural Setting and Earthquakes}

Possible relationship between SP subsidence and recent tectonic activity relies on the analysis of structural lineaments reported into the Italy Hazard from Capable faults database [46]. According to the main faults bounding the SP, we subdivided it in three sectors (Figure 5a) and with foreseen different deformation patterns for the three sectors from InSAR ascending and descending time series (Figure 6). The analysis of the averaged Envisat displacement time series show very similar trends for the three investigated areas, although with different absolute values. On the other hand, COSMO-SkyMed time series show a different deformation pattern for each sector. 


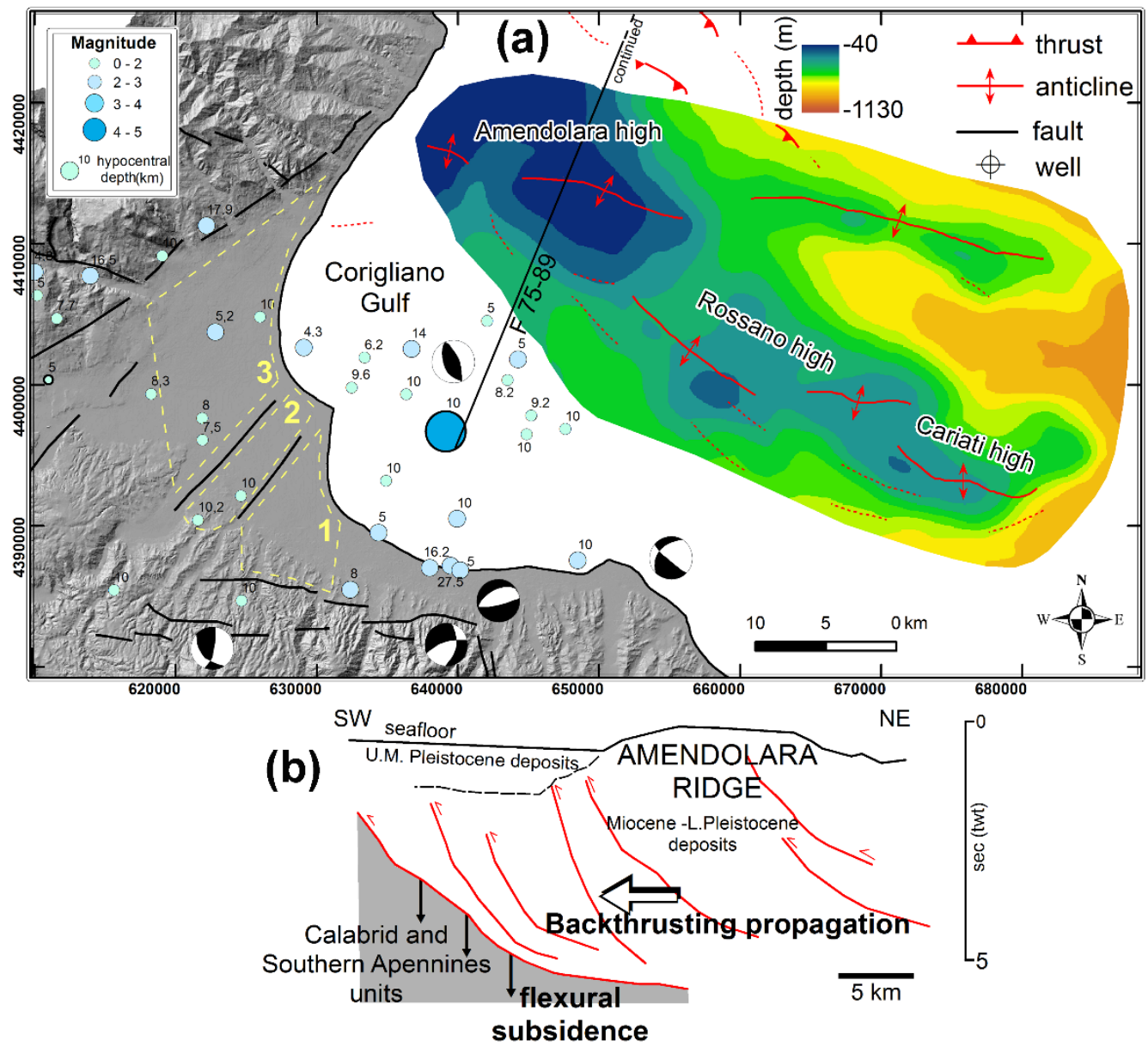

Figure 5. (a) The Amendolara Ridge located in the Ionian Sea in front of the Sibari Plain. The bathymetric map (modified from [73]) shows the presence of three morphological highs (Amendolara, Rossano and Cariati highs). The main structural elements (thrusts and anticlines) are extracted from [71]. In the map is showed the hypocenters location of the earthquakes occurred between 2003 and 2010 (ISIDe [74]) with the relative magnitude and hypocentral depth. Onshore capable faults from [46] and focal mechanisms from [45]. Yellow dashed lines are the boundaries of three selected sectors (1. Corigliano; 2. Crati Delta; 3. Sibari-Villapiana) for Envisat and COSMO-SkyMed time series analysis (Figure 6). (b) Sketch (based on the interpretation of the seismic profile F75-89 of [45]) representing the trigger of the flexural subsidence due to the overlap of the Amendolara Ridge back thrusts on Calabrid and Southern Apennines units.

In detail, the ascending time series reveal a general trend characterized by an increase of the negative displacements but with greater absolute values in the southern sector. The descending time series highlight an increase of negative displacements in the Corigliano sector with values between $10 \mathrm{~mm}$ and $-5 \mathrm{~mm}$ in the Villapiana-Sibari sector, and an expected increasing positive trend in the Crati Delta sector. This trend can be related to the presence of a horst bounded by Crati and Timparelle faults [48].

A comparison between ground deformation pattern and seismicity was performed taking into account the earthquakes occurrences and magnitude [74] during the time covered by SAR data (Figure 5a). No significant earthquakes struck the study area excepting for one shallow offshore M 4.5 event on 27 June 2006 [74] with none ground deformation effects (Figure 6).

Therefore, we can exclude the presence of seismically-induced displacement and we hypothesize that the structural settings could indirectly influence the ground subsidence phenomena. 

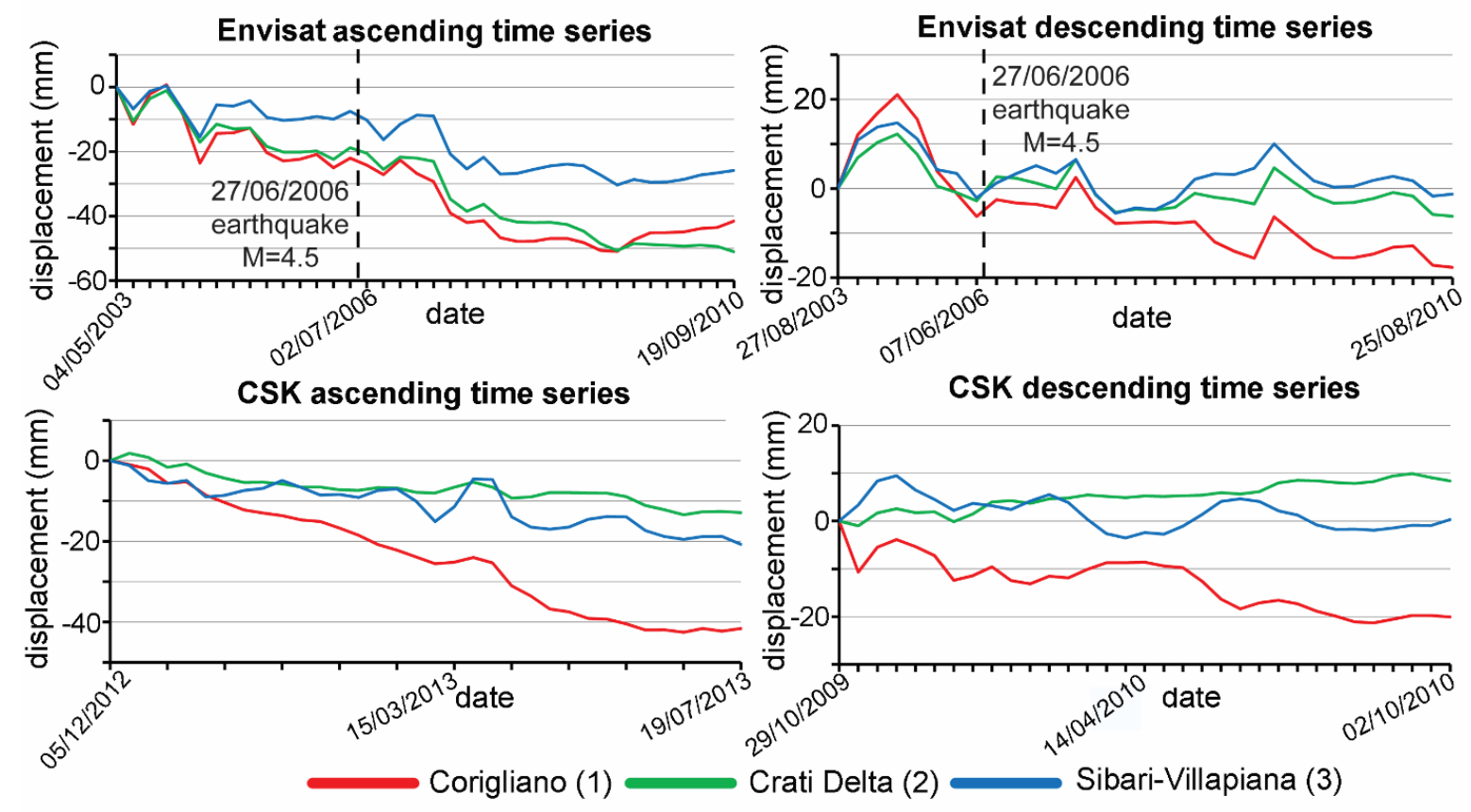

Figure 6. Envisat and COSMO-SkyMed both ascending and descending time series (error $= \pm 1 \mathrm{~mm}$ ) for the three selected sectors delimited by ITHACA [46] faults (location in Figure 5). Black dotted line represents the earthquakes $(\mathrm{M}=4.5)$ occurred on 27 June 2006.

\subsection{Role of the Plio-Quaternary Succession Load}

Possible relationships between subsidence and spatial variation of the Plio-Quaternary succession thickness in the Crati Delta area (Figure 7a) as reconstructed from multichannel seismic profiles and well data [75] was investigated. The thickness observed in the seismic profile has been converted from Two Way Travel time to meter using an average velocity of $2000 \mathrm{~m} / \mathrm{s}$ for the Pliocene and Pleistocene deposits based on the sonic logs, available for Thurio and Ogliastrello wells, analyzed by [44].

The Envisat Vertical component superimposed to the Plio-Quaternary succession isopach map (Figure $7 \mathrm{~b}$ ) shows a prevalent distribution of vertical displacement rates toward the coastline, where the deposits are thicker.

We compared ground velocity profiles, for the Envisat Vertical component, with the corresponding profiles of the Plio-Quaternary deposits thickness. The comparison (Figure 7c) shows a good correlation between the general subsidence trend and the Plio-Quaternary succession thickness. We observed higher subsidence values in the E and NE sectors of Crati Delta, where the Plio-Quaternary succession is thicker. In the SW sector, the reduced thickness corresponds with lower subsidence values. Lower values are also detected in the S-SE sector (Corigliano harbor area), where the presence of shallow igneous-metamorphic bedrock drives the Plio-Quaternary succession thickness.

Furthermore, we considered the ascending and descending ground velocity values in correspondence of the seismic profiles and wells locations, correlating the ground velocity with the thickness of Plio-Quaternary deposits (Figure 8). Both ascending and descending velocities increase with the growth of the succession thickness.

Based on the above analysis results, we found a direct correlation between subsidence spatial trends and distribution of the thickness of Plio-Quaternary deposits, which amplify the subsidence phenomenon as well documented during the evolution of the sedimentary basins [76-81]. 


\subsection{Holocene Deposits}

A possible correlation between subsidence and Holocene sediments compaction was investigated focusing on the lithological features, thickness and stratigraphic architecture of the Holocene deposits.

We analyzed 200 boreholes (Demanio Idrico Prov. Cosenza, [82,83]) and literature data $[57,61,65]$ to define lithology, vertical-lateral variations and thickness of the post-LGM deposits. An isopach map of the Holocene succession superimposed with the Envisat Vertical component was generated (Figure 9a). The greater vertical displacement values are located in the area of the Holocene deposits accumulation but the larger subsidence rates do not correspond to the major depozones.

To well investigate the second topic, we compared each Vertical displacement value of with the corresponding thickness of the Holocene deposits (Figure 9b).We also performed a comparison between thickness and vertical component in correspondence of each borehole, if SAR data are available (Figure 9c).

The analysis reveals that the Holocene sediments compaction does not play a dominant role in the subsidence of the SP area, on the contrary as described for other delta plains $[5,7]$.

Subsidence rates of 3-5 mm/yr induced by to the Holocene deposits consolidation due to phreatic and confined water tables drop are calculated by [66] and are not sufficient to justify the vertical displacements inferred by SAR data.

Although the minor role of Holocene deposits compaction, the boreholes analysis highlights a clear influence of the lateral variations of the sediments lithology for the subsidence phenomena. In detail, we took into account the ground deformation patterns from ascending and descending Envisat data, and the boreholes into the Saraceno and Satanasso alluvial fans areas (Figure 10a), considering the thickness of fine-grained (silt and clay) deposits (Figure 10b,c). Greater ground velocities are usually retrieved close to the boreholes recording a major thickness of fine-grained sediments while the lower values are in correspondence of the coarse-grained (gravel and sand) deposits which made up the alluvial fan bodies. Thus, the lateral variation of the fine-grained materials thickness creates differential land subsidence.

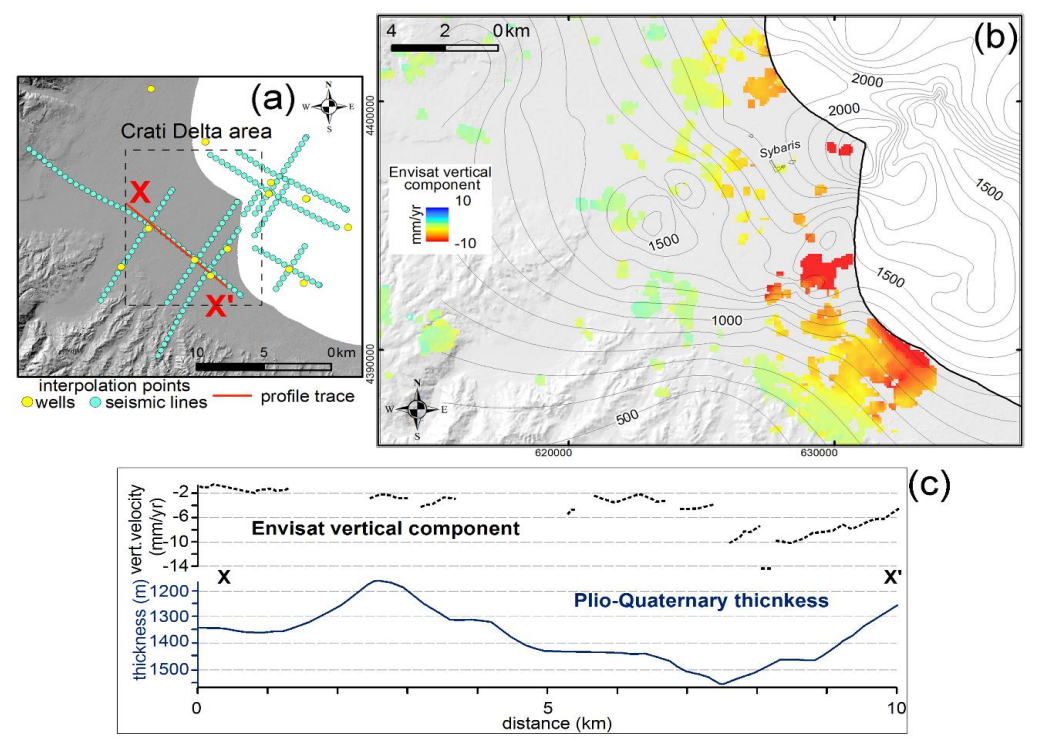

Figure 7. (a) Location of the used wells and seismic profiles. (b) Isopach map of the Plio-Quaternary succession with the distribution of the Envisat Vertical component. (c) Comparison between the thickness of the Plio-Quaternary succession and ground velocity, based on the Envisat Vertical component, along one of the analyzed profiles (its trace in Figure 7a). The discontinuous lines for the InSAR profile are due to missing data in the ascending and/or descending original velocity maps due to coherence lack. 


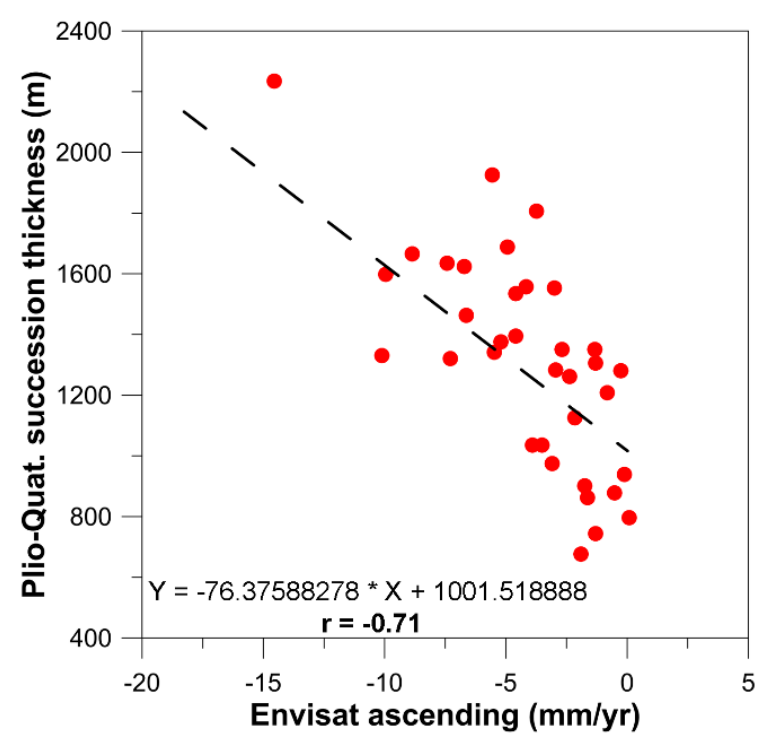

(a)

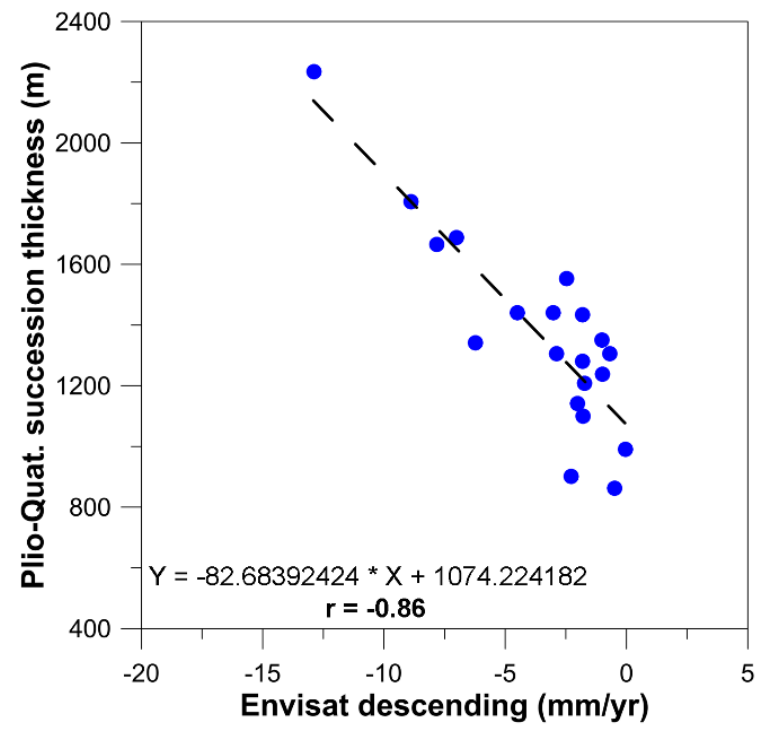

(b)

Figure 8. Correlation between (a) ascending and (b) descending velocities with the thickness of the Plio-Quaternary succession.
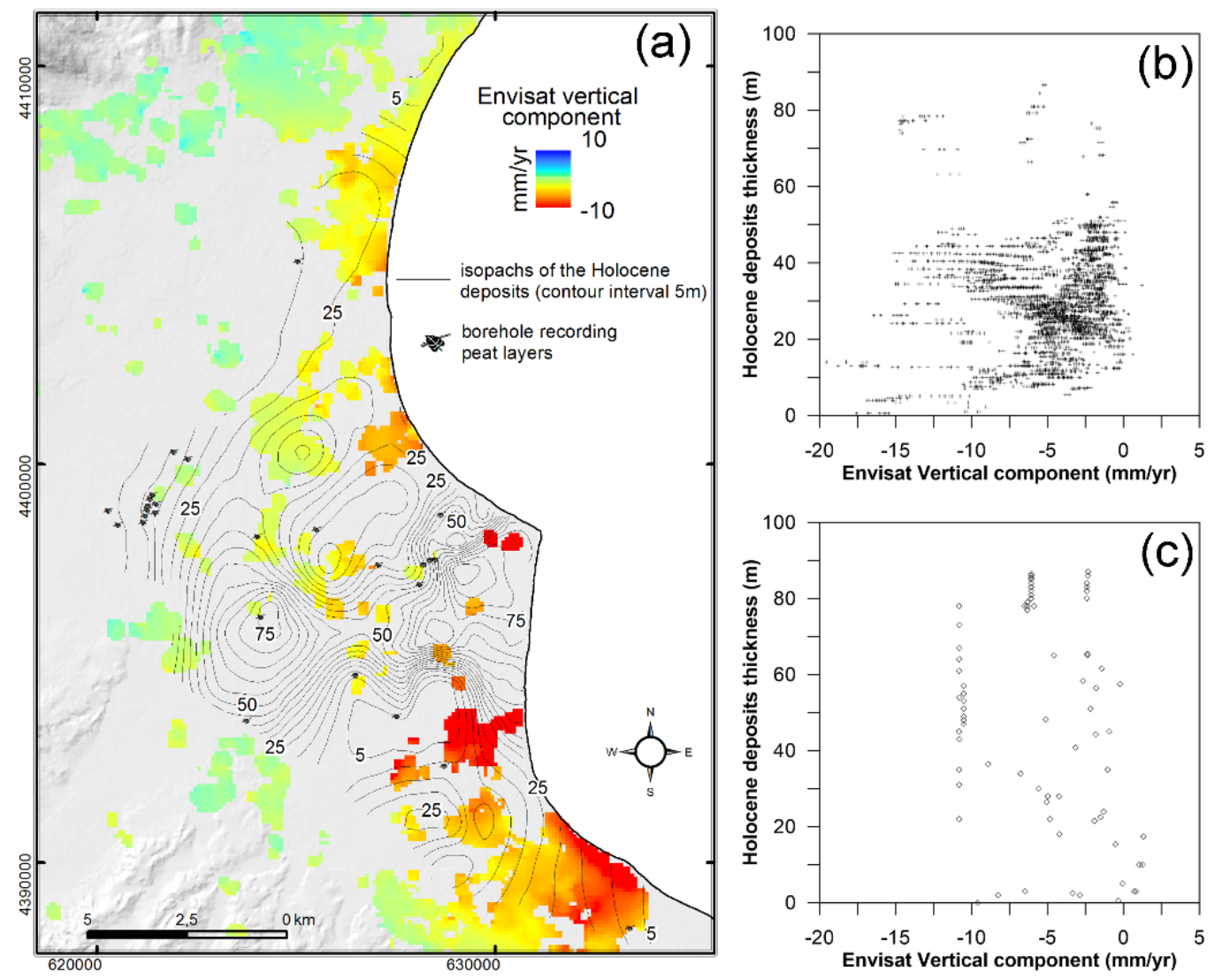

Figure 9. (a) Envisat Vertical component overlapped to the Holocene deposits isopach map. (b) Scatter plot Envisat Vertical component vs. Holocene deposits thickness inferred from isopach map. (c) Comparison between Holocene sediments thickness and Envisat Vertical component in correspondence of each borehole. 

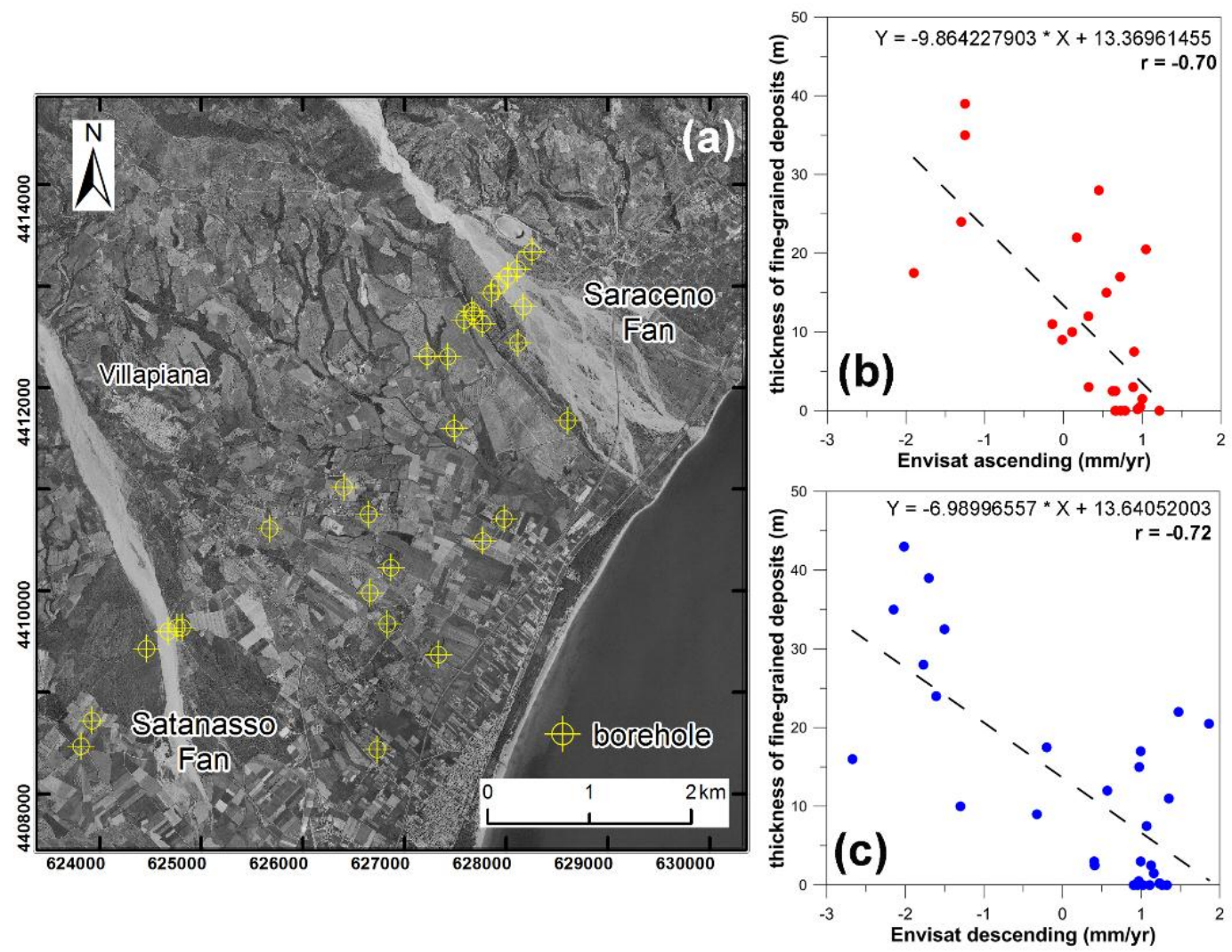

Figure 10. (a) Analyzed boreholes between Saraceno and Satanasso alluvial fans (see Figure 1 for their location). (b) Correlation among Envisat ascending and (c) descending velocity and the thickness of fine-grained deposits (silt and clay).

\subsection{Land Use and Historical Evolution}

SP represents a geomorphological system with a rapid evolution in historical and recent times controlled by geological processes and anthropogenic activities. The present morphological setting results from the works of a 1960s-1990s land reclamation project aimed to convert a marshy area to an agricultural zone. Several widespread agricultural areas (e.g., orchards, arable soils) with localized urban settlements [84] are present in SP.

In order to define land use variations, we analyzed the 1954 and 1998 aerial photos; for a detailed analysis of urban area growth effects. We considered three areas (Marina di Sibari; Laghi di Sibari and C.da Ricota; see Figure 4), characterized by the same subsoil stratigraphy, and compared the Envisat ascending and descending displacement time series concerning urban and agricultural zones respectively (Figure 11).

In Laghi di Sibari and C.da Ricota sites, we observe a progressive temporal differentiation in the subsidence values that increase faster in urban areas reaching a maximum difference compared with agricultural ones of $\sim 35 \mathrm{~mm}$ in August 2010 (for the descending track) and of $\sim 25 \mathrm{~mm}$ in September 2010 (for the ascending one). The subsidence values are very similar for the two considered sectors in the Marina di Sibari zone, where the descending time series show a little increase $(\sim 5 \mathrm{~mm})$ of ground deformation values into the urban area.

We observed a diffuse subsidence irrespective of the land use, with some increments of deformation velocity in correspondence of Laghi di Sibari and C.da Ricota settlements.

Therefore, we suggest that the urban-induced loading represents an incremental factor of subsidence. 


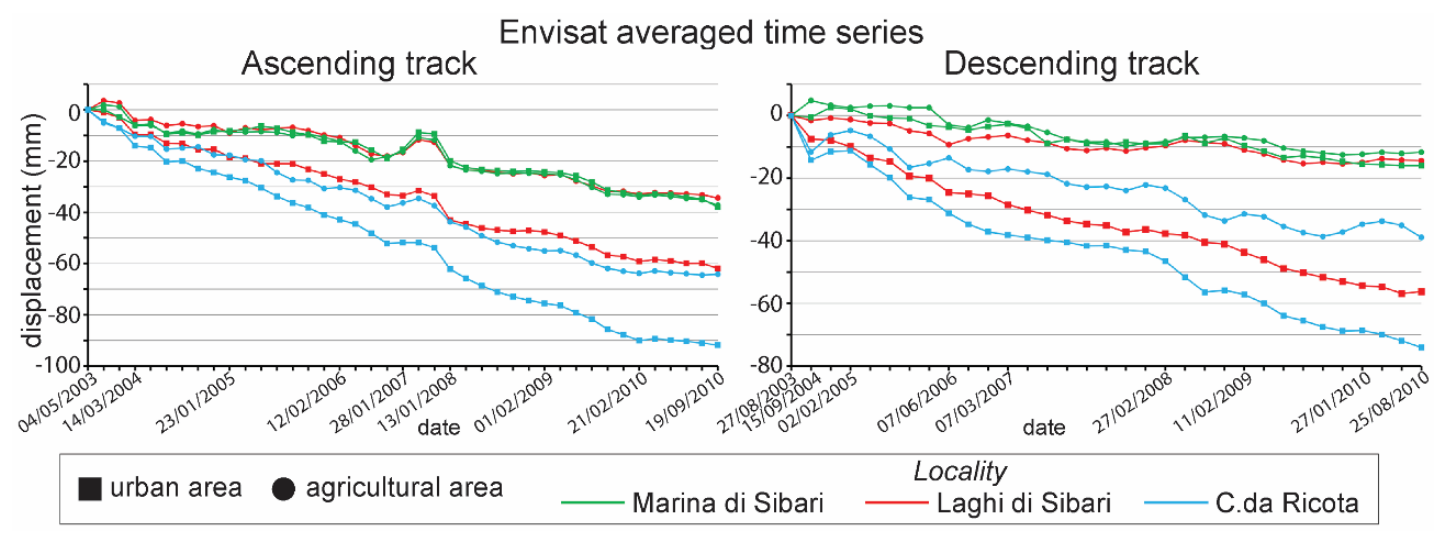

Figure 11. Envisat ascending and descending time series (error $= \pm 1 \mathrm{~mm}$ ) comparison between urban and agricultural areas for three selected sectors (see Figure 4 for their location).

\subsection{Water Table Variations}

SP is characterized by two well-defined aquifers: the shallower one (from soil surface to $-20 /-30 \mathrm{~m}$ above sea level) separated by clayey and silty-clayey layer and the deeper one (from $-50 /-60 \mathrm{~m}$ a.s.l.) [85]. Both the aquifers are characterized by intense water exploitation. The piezometric level variations of the shallow one shows 5 meters of drop between 1930s and $2002[86,87]$.

We investigated to find possible correlation between groundwater exploitation and ground deformation comparing the spatial distribution of phreatic water table variations in the time interval 1930s-2002 [86] and the Vertical velocity distribution from Envisat and COSMO-SkyMed data in the following 2003-2013 time interval (Figure 12). In the most recent period, we have observed that subsidence is present in areas showing rise, drop and stability of the water table.

Considering the effect of water table variation between 2002 (data from [86]) and 2013 (this work), we analyzed the distribution of the Vertical velocity (from Envisat and COSMO-SkyMed data, Figure 12). The subsidence location does not show a strict correlation with the water table drop.
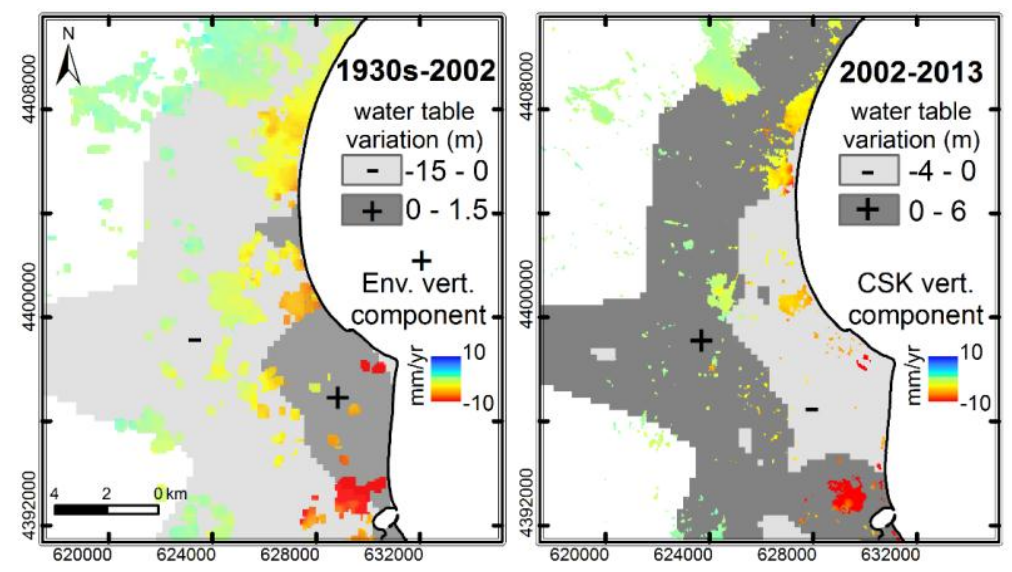

Figure 12. Envisat and COSMO-SkyMed Vertical component superimposed respectively on the maps of the water table variations 1930s-2002 (redrawn from [86]) and 2002-2013.

We selected 6 wells (Figure 1), with piezometric records in 2002 and 2013, and we analyzed the Envisat time series for both ascending and descending orbit (Figure 13) considering a circular buffer of $500 \mathrm{~m}$ radius. For the two wells No. 2 and 3, showing a groundwater drawdown, we observe a displacement trend similar to the No. 1, 4, 5 and 6 ones characterized by water table rise. Moreover, 
the time series show smaller displacements rates in correspondence of the well No. 2. There is no evidence of correlation between water table variation and displacement time series, probably because the progressive groundwater level stabilization from 2002 to 2013. In contrast, the groundwater level drop between 1930s and $2002[86,87]$ could have been caused by a more recent consolidation process of soft materials as observed by [88] in the Alto Guadalentin Basin.

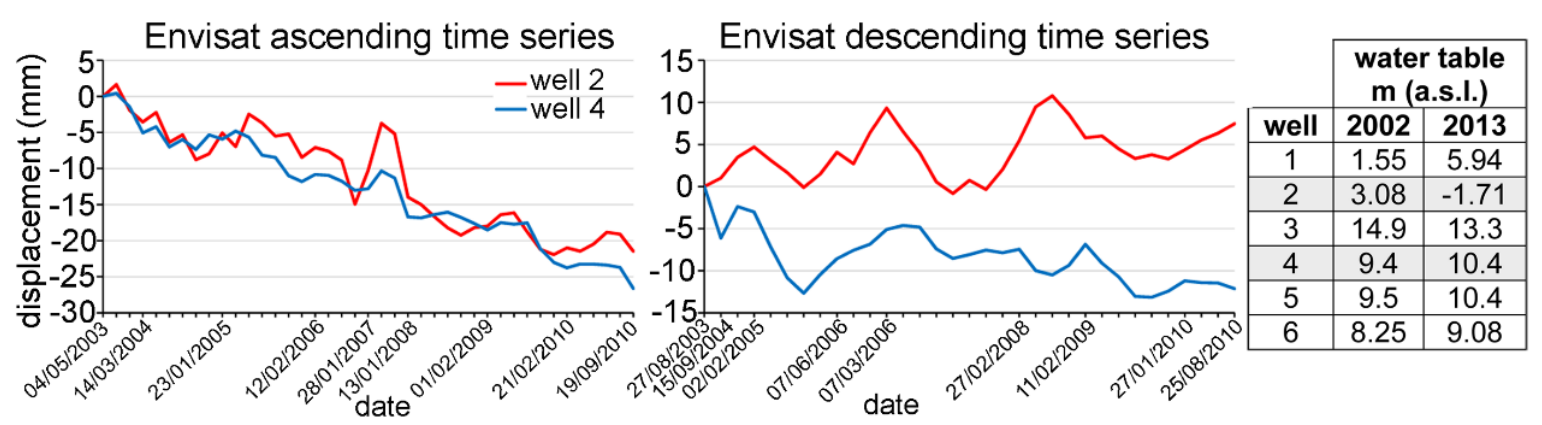

Figure 13. Envisat (both ascending and descending orbit) time series of the wells No. 2 and No. 4 (see Figure 1 for their location) recording respectively a water table drop and rise. In table are reported the water table variation between 2002 and 2013 for each well.

For the confined aquifer, the lack of historical data did not allow us to analyze the effects of its variations on subsidence.

Therefore, we conclude that water table variations are only an incremental factor of subsidence in some areas as the Sybaris archaeological area (see Figure 2 to localize Sybaris site), where a well-points system $(80 \mathrm{l} / \mathrm{s})$ works every time to maintain the excavations above the water table. Moreover, in these areas, a water depletion in compressible soils could trigger an amplified and long-term subsidence as shown in other Quaternary basins $[88,89]$.

\section{Conclusions}

InSAR results from data acquired by Envisat and COSMO-SkyMed satellites, and spanning from 2003 to 2013, are able to detect ground displacements in the SP area (Calabria, Southern Italy). The ground deformation field is dominated by a widespread-subsidence with rate up to $\sim 20 \mathrm{~mm} / \mathrm{yr}$.

We can summarize that the location of the SP in an area marked by geodynamic and geological complexity precluding the attribution of the ground deformation triggering factor to a unique subsidence mechanism.

We suppose that the active oblique-contractional belt in the Ionian Sea in front of SP [45] can trigger a flexural subsidence mechanism due to the back thrusting load above the underlying Calabrid and Southern Apennines Units. Furthermore, the observed correlation between Plio-Quaternary sediments thickness and ground deformation suggests that the isostatic compensation plays a major role in the SP present subsidence. We highlight the absence of correlation between the occurring earthquakes close to the main capable faults, so excluding the contribution of faulting activity and earthquakes for the present SP subsidence phenomena, according to [67] (based on geomorphological data); we hypothesize that the structural settings could indirectly influence the ground subsidence phenomena.

Another minor triggering mechanism of subsidence is represented by the compaction of the compressible fine-grained sediments related to the Holocene post-LGM transgression and following Crati Delta progradation. We show the effect of the lateral transition between fine- and coarse-grained Holocene sediments on the ground deformation spatial pattern.

Anthropogenic activities can be considered as an incremental factor of the SP subsidence. In fact, we observe higher subsidence velocities in the more anthropized areas, where soil compaction is amplified by urban-induced loading. In some area showing excessive water withdrawals (e.g., 
Sybaris archaeological site), water table variations may increase the deformation velocity because can be the origin of delayed consolidation process in soft materials.

The presence of subsidence phenomenon in the whole SP and the complicated identification of a main triggering mechanism, due to the peculiar geological setting, is also in agreement with [90].

The results of this study show as the deformation field of complex basins may be due to coexisting regional and local natural processes and anthropic activities. To better assess and monitor the hazard(s) related to the detected ground deformation phenomena, a multiparametric monitoring of SP area would be recommended.

Acknowledgments: This paper is sponsored by PON (Operational National Plan) 2007-2013 from MIUR (Italian Research Ministry of Research) Project AMICUS (Study for the environmental protection and the mitigation of Anthropogenic Pollution In the Coastal Environment of selected areas of Calabria; ID: PON01_02818) and resulted from the Ph.D. work of Giuseppe Cianflone. Results carried out using COSMO-SkyMed ${ }^{\circledR}$ PRODUCTS, (C) ASI (Italian Space Agency)-provided under license of ASI in the framework of the S3 Project "Short term earthquake prediction and preparation" (DPC-INGV, 2013). The Envisat images are provided by ESA (European Space Agency) under the CAT.1P 5605. The InSAR processing are carried out using the Sarscape ${ }^{\odot}$ software (Sarmap, CH). We thank Paolo Riccardi and Alessio Cantone (Sarmap, CH) for the fruitful collaboration and useful suggestions during the SAR data processing. We also thank Enrico Serpelloni (INGV-Bo) for providing the GPS solutions. We are grateful to G. Ventura for his careful and critical reading of the manuscript. We thank editors and four anonymous reviewers, which improved the paper quality with their suggestions.

Author Contributions: All authors participated in the writing of the manuscript, and have read and approved the final manuscript. Giuseppe Cianflone developed the project and conducted the geological survey. All authors analyzed and interpreted the data. Cristiano Tolomei processed the SAR data.

Conflicts of Interest: The authors declare no conflict of interest.

\section{References}

1. Jelgersma, S. Land subsidence in coastal lowlands. In Sea-Level Rise and Coastal Subsidence; Milliman, J.D., Haq, B.U., Eds.; Kluwer Academic Publishers: Dordrecht, Netherlands, 1996; pp. 47-62.

2. Ericson, J.P.; Vörösmarty, C.J.; Dingman, S.L.; Ward, L.G.; Meybeck, M. Effective sea-level rise and deltas: Causes of change and human dimension implications. Global Planet. Change 2006, 50, 63-82. [CrossRef]

3. Carminati, E.; Doglioni, C.; Scrocca, D. Apennines subduction related subsidence of Venice (Italy). Geophys. Res. Lett. 2003, 30. [CrossRef]

4. Teatini, P.; Tosi, L.; Strozzi, T.; Carbognin, L.; Wegmüller, U.; Rizzetto, F. Mapping regional land displacements in the Venice coastland by an integrated monitoring system. Remote Sens. Environ. 2005, 98, 403-413. [CrossRef]

5. Tosi, L.; Teatini, P.; Strozzi, T. Natural versus anthropogenic subsidence of Venice. Nat. Sci. Rep. 2013. [CrossRef] [PubMed]

6. Carbognin, L.; Teatini, P.; Tosi, L. Relative land subsidence in the lagoon of Venice, Italy, at the beginning of the new millennium. J. Mar. Syst. 2004, 51, 345-353. [CrossRef]

7. Ivins, E.R.; Dokka, R.K.; Blom, R. Post glacial sediment load and subsidence in coastal Louisiana. Geophys. Res. Lett. 2007, 34, L16303. [CrossRef]

8. Dokka, R.K. Modern day tectonic subsidence in coastal Louisiana. Geology 2006, 34, 281-284. [CrossRef]

9. Dokka, R.K. The role of deep processes in late 20th century subsidence of New Orleans and coastal areas of Southern Louisiana and Mississippi. J. Geophys. Res. 2011, 116, B06403. [CrossRef]

10. Meckel, T.A.; ten Brink, U.S.; Williams, S.J. Current subsidence rates due to compaction of Holocene sediments in Southern Louisiana. Geophys. Res. Lett. 2006, 33, L11403. [CrossRef]

11. Morton, R.A.; Bernier, J.C.; Barras, J.A. Evidence of regional subsidence and associated interior wetland loss induced by hydrocarbon production, Gulf Coast region, USA. Environ. Geology 2006, 50, $261-274$. [CrossRef]

12. Liu, J.; Huang, H.J. Characterization and mechanism of regional land subsidence in the Yellow River Delta, Chin. Nat. Hazard. 2013, 68, 687-709. [CrossRef]

13. Shi, X.; Xue, Y.; Wu, J.; Ye, S.; Zhang, Y.; Wei, Z.; Yu, J. Characterization of regional land subsidence in Yangtze Delta, China: The example of Su-Xi-Chang area and the city of Shanghai. Hydrogeol. J. 2008, 16, 593-607. [CrossRef] 
14. Liu, C.H.; Pan, Y.W.; Liao, J.J.; Huang, C.T.; Ouyang, S. Characterization of land subsidence in the Choshui River alluvial fan, Taiwan. Environ. Geology 2004, 45, 1154-1166. [CrossRef]

15. Hsieh, C.S.; Shih, T.Y.; Hu, J.C.; Tung, H.; Huang, M.H.; Angelier, J. Using differential SAR interferometry to map land subsidence: A case study in the Pingtung Plain of SW Taiwan. Nat. Hazard. 2011, 58, 1311-1332. [CrossRef]

16. Tung, H.; Hu, J.C. Assessments of serious anthropogenic land subsidence in Yunlin County of central Taiwan from 1996 to 1999 by Persistent Scatterers InSAR. Tectonophysics 2012, 578, 126-135. [CrossRef]

17. Lubis, A.M.; Toshinori, S.; Tomiyama, N.; Isezaki, N.; Yamanokuchi, T. Ground subsidence in Semarang-Indonesia investigated by ALOS-PALSAR satellite SAR interferometry. J. Asian Earth Sci. 2011, 40, 1079-1088. [CrossRef]

18. Stiros, S.C. Subsidence of Thessaloniki (Northern Greece) coastal plain, 1960-1999. Eng. Geol. 2011, 61, 243-256. [CrossRef]

19. Raspini, F.; Loupasakis, C.; Rozos, D.; Adam, N.; Moretti, S. Ground subsidence phenomena in the Delta municipality region (Northern Greece): Geotechnical modeling and validation with Persistent Scatterer Interferometry. Int. J. Appl. Earth Obs. Geoinf. 2014, 28, 78-89. [CrossRef]

20. Berardino, P.; Fornaro, G.; Lanari, R.; Sansosti, E. A new algorithm for surface deformation monitoring based on small baseline differential SAR interferograms. IEEE Trans. Geosci. Remote Sens. 2002, 40, 2375-238. [CrossRef]

21. Adam, N.; Kampes, B.; Eineder, M.; Worawattanamateekul, J.; Kircher, M. The development of a scientific permanent scatterer system. In Proceedings of the 2003 ISPRS Workshop on High Resolution Mapping from Space, Hannover, Germany, 6-8 October 2003.

22. Crosetto, M.; Arnaud, A.; Duro, J.; Biescas, E.; Agudo, M. Deformation monitoring using remotely sensed radar interferometric data. In Proceedings of the 11th FIG Symposium on Deformation Measurements, Santorini, Greece, 25-28 May 2003.

23. Ferretti, A.; Prati, C.; Rocca, F. Permanent scatters in SAR interferometry. IEEE Trans. Geosci. Remote Sens. 2001, 39, 8-20. [CrossRef]

24. Kampes, B.M. Radar Interferometry: Persistent Scatterer Technique; Springer: Dordrecht, The Netherlands, 2006.

25. Lyons, S.; Sandwell, D. Fault creep along the Southern San Andreas from interferometric synthetic aperture radar, permanent scatterers, and stacking. J. Geophys. Res. 2003, 108, 2047-2070. [CrossRef]

26. Werner, C.; Wegmüller, U.; Strozzi, T.; Wiesmann, A. Interferometric point target analysis for deformation mapping. In Proceedings of the 2003 IEEE International Conference on Geoscience and Remote Sensing Symposium, Toulouse, France, 21-25 July 2003.

27. Hooper, A.; Zebker, H.; Segall, P.; Kampes, B. A new method for measuring deformation on volcanoes and other natural terrains using InSAR persistent scatterers. Geophys. Res. Lett. 2004, 31, L23611. [CrossRef]

28. Van der Kooij, M.; Hughes, W.; Sato, S.; Poncos, V. Coherent target monitoring at high spatial density: Examples of validation results. In Proceedings of the 5th International Workshop on Automatic Processing of Finge Patterns, Frascati, Italy, 1-5 December 2005.

29. Hooper, A.; Bekaert, D.; Spaans, K.; Arıkan, M. Recent advances in SAR interferometry time series analysis for measuring crustal deformation. Tectonophysics 2012, 514, 1-13. [CrossRef]

30. Malinverno, A.; Ryan, W.B.F. Extension in Tyrrhenian sea \& shortening in the Apennines as result of arc migration driven bysinking of the lithosphere. Tectonics 1986, 5, 227-254.

31. Faccenna, C.; Mattei, M.; Funiciello, R.; Jolivet, L. Styles of back-arc extension in the central Mediterranean. Terra N. 1997, 9, 126-130. [CrossRef]

32. Gueguen, E.; Doglioni, C.; Fernandez, M. On the post 25 Ma geodynamic evolution of the western Mediterranean. Tectonophysics 1998, 298, 259-269. [CrossRef]

33. Patacca, E.; Scandone, P. Post-Tortonian mountain building in the Apennines: The role of the passive sinking of a relic lithospheric slab. Adv. Earth Sci. Res. 1989, 80, 157-176.

34. Patacca, E.; Scandone, P. Geology of the Southern Apennines. Boll. Soc. Geol. Ital. 2005, 7, 75-119.

35. Roure, F.; Casero, P.; Vially, R. Growth processes and mélange formation in the Southern Apennines accretionary wedge. Earth Planet. Sci. Lett. 1991, 102, 395-412. [CrossRef]

36. Cello, G.; Mazzoli, S. Apennine tectonics in Southern Italy: A review. J. Geodyn. 1999, 27, $191-211$. [CrossRef] 
37. Cello, G.; Tortorici, L.; Turco, E.; Guerra, I. Profili profondi in Calabria settentrionale. Boll. Soc. Geol. Ital. 1981, 109, 423-431.

38. Istituto Superiore per la Protezione e la Ricerca Ambientale (ISPRA). 2009. Available online: http:/ / www.apat.gov.it (accessed on 8 February 2014).

39. Selli, R. Il Paleogene nel quadro della geologia dell'Italia centro-meridionale. Mem. Soc. Geol. Ital. 1962, 3, 737-789.

40. Caruso, C.; Ceravolo, R.; Cianflone, G.; Dominici, R.; Sonnino, M. Sedimentology and ichnology of Plio-Pleistocene marine to continental deposits in Broglio (Trebisacce, Northern ionian Calabria, Italy). J. Mediterr. Earth Sci. 2013, 21, 21-24.

41. Spadea, P.; Lanzafame, G.; Tortorici, L. Serie ofioliti fere nell'area fra Tarsia e Spezzano Albanese (Calabria): stratigrafia, petrografia, rapporti strutturali. Mem. Soc. Geol. Ital. 1976, 17, 135-174.

42. Ghisetti, F. Evoluzione neotettonica dei principali sistemi di faglie della Calabria centrale. Boll. Soc. Geol. Ital. 1979, 98, 387-430.

43. Turco, E.; Maresca, R.; Cappadona, P. La tettonica Plio-pleistocenica del confine Calabro-lucano: modello cinematico. Mem. Soc. Geol. Ital. 1990, 45, 519-529.

44. Spina, V.; Tondi, E.; Mazzoli, S. Complex basin development in a wrench-dominated back-arc area: Tectonic evolution of the Crati Basin, Calabria, Italy. J. Geodyn. 2011, 51, 90-109. [CrossRef]

45. Ferranti, L.; Santoro, E.; Mazzella, M.E.; Monaco, C.; Morelli, D. Active transpression in the Northern Calabria Apennines, Southern Italy. Tectonophysics 2009, 476, 226-251. [CrossRef]

46. Comerci, V.; Blumetti, A.M.; Di Manna, P.; Fiorenza, D.; Guerrieri, L.; Lucarini, M.; Serva, L.; Vittori, E. ITHACA Project and capable faults in the Po Plain (Northern Italy). Ing. Sismica 2013, 30, 36-45.

47. Cinti, F.R.; Alfonsi, L.; D'Alessio, A.; Marino, S.; Brunori, C.A. Faulting and ancient earthquakes at Sybaris archaeological site, Ionian Calabria, Southern Italy. Seismol. Res. Lett. 2015, 86, 245-254. [CrossRef]

48. Lanzafame, G.; Tortorici, L. La tettonica recente della Valle del Fiume Crati (Calabria). Geogr. Fis. Din. Quat. 1981, 4, 11-22.

49. Bigi, G.; Bonardi, G.; Catalano, R.; Cosentino, D.; Lentini, F.; Parlotto, M.; Sartori, R.; Scandone, P.; Turco, E. Structural Model of Italy, 1:500.000; Consiglio Nazionale delle Ricerche: Rome, Italy, 1992.

50. Cucci, L. Raised marine terraces in the Northern Calabrian Arc (Southern Italy): A 600 Ka-long geological record of regional uplift. Ann. Geophys. 2004, 47, 1391-1406.

51. Ciaranfi, N.; Ghisetti, F.; Guida, M.; Iaccarino, G.; Pieri, P.; Rapisardi, L.; Ricchetti, G.; Torre, M.; Tortorici, L.; Vezzani, L. Carta neotettonica dell'Italia meridionale. Prog. Fin. Geod. Pub. 1983, 515, 1-62.

52. Molin, P.; Pazzaglia, F.J.; Dramis, F. Geomorphic expression of active tectonics in a rapidly-deforming forearc, Sila Massif, Calabria, Southern Italy. Am. J. Sci. 2004, 304, 559-589. [CrossRef]

53. Valensise, G.; Pantosti, D. Database of potential sources for earthquakes larger than 5.5 in Italy. Ann. Geophys. 2001, 44, 175.

54. Cucci, L.; Cinti, F.R. Regional uplift and local tectonic deformation recorded by the Quaternary marine terraces on the Ionian coast of Northern Calabria (Southern Italy). Tectonophysics 1998, 292, 67-83. [CrossRef]

55. Santoro, E.; Mazzella, M.E.; Ferranti, L.; Randisi, A.; Napolitano, E.; Rittner, S.; Radtke, U. Raised coastal terraces along the Ionian Sea coast of Northern Calabria, Italy, suggest space and time variability of tectonic uplift rates. Quat. Int. 2009, 206, 78-101. [CrossRef]

56. Bellotti, P.; Caputo, C.; Dell'Aglio, P.L.; Davoli, L.; Ferrari, K. Insediamenti urbani in un paesaggio in evoluzione: Interazione uomo-ambiente nella Piana di Sibari (Calabria ionica). Il Quat. Ital. J. Quat. Sci. 2009, 22, 61-72.

57. Cianflone, G. Geological, Stratigraphic and Hydrostratigraphic Setting of the Lower Crati Valley Reconstructed by Geophysical and Well Data and Relationship with the Land Subsidence Detected by InSAR Data. Ph.D. Thesis, Università della Calabria, Arcavacata di Rende (Cs), Italy, 2015.

58. Stanley, J.D.; Bernasconi, M.P. Sybaris-Thuri-Copia trilogy: Three delta coastal sites become land-locked. Mediterr. Geogr. 2009, 112, 75-86. [CrossRef]

59. Bernasconi, M.P.; Stanley, J.D.; Caruso, C. Sybaris-Thuri-Copia deltaic settings in Calabria, Italy: Molluscs, associated biogenic components, and ecobiostratigraphy applied to archaeology. J. Coast. Res. 2010, 26, 377-390. [CrossRef]

60. Rainey, F.G.; Lerici, C.M. The Search for Sybaris 1960-1965; Lerici Editori: Rome, Italy, 1967. 
61. Guerricchio, G.; Melidoro, G. Ricerche di geologia applicata all'archeologia della città di Sybaris sepolta. Geol. Appl. Idrogeol. 1975, 10, 107-128.

62. Cotecchia, V.; Cherubini, C.; Pagliarulo, R. Geotechical characteristics of outcropping deposits in Sibari plain. In Proceedings of the XIII International Conference of Soil Mechanics and Foundation Engineering, New Delhi, India, 5-10 January 1994.

63. Pagliarulo, R.; Cotecchia, F.; Coop, M.R.; Cherubini, C. Studio litostratigrafico e geotecnico della Piana di Sibari con riferimento all'evoluzione morfologica e ambientale del sito archeologico. Geol. Appl. Idrogeol. 1995, 30, 375-391.

64. Cotecchia, V.; Pagliarulo, R. State of the art in geological, hydrogeological and geotechnical researches carried on the archaeological site of Sybaris. Geol. Appl. Idrogeol. 1996, 31, 43-54.

65. Cherubini, C.; Cotecchia, V.; Pagliarulo, R. Subsidence in the Sybaris Plain (Italy). In Proceedings of the 6th International Symposium on Land Subsidence, Ravenna, Italy, 24-29 September 2000.

66. Cafaro, F.; Cotecchia, F.; Lenti, V. Interpretation and modelling of the subsidence at the archeaelogical site odf Sybaris (Southern Italy). In Geotechnical Engineering for the Preservation of Monuments and Historic Sites; Bilotta, E., Flora, A., Lirer, S., Viggiani, C., Eds.; Taylor \& Francis Group: London, England, 2013; pp. 199-206.

67. Cucci, L. Geology versus myth: The Holocene evolution of the Sybaris Plain. Ann. Geophys. 2005, 48, 1017-1033.

68. Ferranti, L.; Pagliarulo, R.; Antonioli, F.; Randisi, A. Punishment for the sinner: Holocene episodic subsidence and steady tectonic motion at ancient Sybaris (Calabria, Southern Italy). Quat. Int. 2011, 232, 56-70. [CrossRef]

69. Massonnet, D.; Feigl, K.L. Radar interferometry and its application to changes in the earth's surface. Rev. Geophycs. 1998, 36, 441-500. [CrossRef]

70. Casu, F.; Manzo, M.; Lanari, R. A quantitative assessment of the SBAS algorithm performance for surface deformation retrieval from DInSAR data. Remote Sens. Environ. 2006, 102, 195-210. [CrossRef]

71. Ferranti, L.; Burrato, P.; Pepe, F.; Santoro, E.; Mazzella, M.E.; Morelli, D.; Passaro, S.; Vannucci, G. An active oblique-contractional belt at the transition between the Southern Apennines and Calabrian Arc: The Amendolara Ridge, Ionian Sea, Italy. Tectonics 2014, 33, 2169-2194. [CrossRef]

72. Carapa, B.; Garcia-Castellanos, D. Western Alpine back-thrusting as subsidence mechanism in the Tertiary Piedmont Basin (Western Po Plain, NW Italy). Tectonophysics 2005, 406, 197-212. [CrossRef]

73. Rebesco, M.; Neagu, R.C.; Cuppari, A.; Muto, F.; Accettella, D.; Dominici, R.; Cova, A.; Romano, C.; Caburlotto, A. Morphobathymetric analysis and evidence of submarine mass movements in the western Gulf of Taranto (Calabria margin, Ionian Sea). Int J. Earth Sci. 2009, 98, 791-805. [CrossRef]

74. ISIDe. Italian Seismological Instrumental and Parametric Data-Base. Istituto Nazionale di Geofisica e Vulcanologia. Available online: http://iside.rm.ingv.it/iside/standard/index.jsp (accessed on 9 October 2014).

75. ViDEPI. Visibilità Dati Esplorazione Petrolifera in Italia. Available online: http://unmig.sviluppoec onomico.gov.it/videpi/kml/webgis.asp (accessed on 25 January 2014).

76. Watts, A.B.; Ryan, W.B.F. Flexure of the lithosphere and continental margin basins. Tectonophysics 1976, 36, 25-44. [CrossRef]

77. Beaumont, C. The evolution of sedimentary basins on a viscoelastic lithosphere: Theory and examples. Geophys. J. Int. 1978, 55, 471-497. [CrossRef]

78. Bessis, F. Some remarks on the study of subsidence of sedimentary basins Application to the Gulf of Lions margin (Western Mediterranean). Mar. Petrol. Geol. 1986, 3, 37-63. [CrossRef]

79. Watts, A.B. Lithospheric flexure due to prograding sediment loads: Implications for the origin of offlap/onlap patterns in sedimentary basins. Basin Res. 1989, 2, 133-144. [CrossRef]

80. Reynolds, D.J.; Steckler, M.S.; Coakley, B.J. The role of the sediment load in sequence stratigraphy: The influence of flexural isostasy and compaction. J. Geophys. Res. 1991, 96, 6931-6949. [CrossRef]

81. Morley, C.K.; Westaway, R. Subsidence in the super-deep Pattani and Malay basins of Southeast Asia: A coupled model incorporating lower-crustal flow in response to post-rift sediment loading. Basin Res. 2006, 18, 51-84. [CrossRef]

82. CASMEZ (Cassa Speciale per il Mezzogiorno). Progetto Speciale 26. 1987.

83. Indagini Nel Sottosuolo (L.464/84). ISPRA. Available online: http://sgi.isprambiente.it/GMV2/index.html (accessed on 10 June 2013). 
84. Corine Land Cover 2006. ISPRA. Available online: http://www.pcn.minambiente.it/viewer/ (accessed on 10 January 2014).

85. Polemio, M.; Luise, G. Conceptual and numerical model of groundwater flow for a coastal plain (Piana di Sibari, Southern Italy). In Proceedings of the XXXV IAH Congress: Groundwater and Ecosystems, Lisbon, Portugal, 17-21 September 2007.

86. Polemio, M.; Petrucci, O.; Gatto, L. Suscettività alla siccità in Calabria ed effetti sulle acque sotterranee. Atti Conv. Lincei-Accad. Naz. Lincei 2004, 204, 245-250.

87. Polemio, M.; Dragone, V.; Romanazzi, A. La risorsa idrica. Sfruttamento, depauperamento dei serbatoi sotterranei e utilizzo razionale nel caso della Calabria. In Rendiconti Accademia Nazionale delle Scienze detta dei XL; Dramis, F., Mottana, A., Eds.; Aracne: Rome, Italy, 2013; pp. 2-29.

88. Bonì, R.; Herrera, G.; Meisina, C.; Notti, D.; Béjar-Pizarro, M.; Zucca, F.; Gonzàlez, P.J.; Palano, M; Tomàs, R.; Fernàndez, J.; et al. Twenty-year advanced DIn-SAR analysis of severe land subsidence: The Alto Guadalentín Basin (Spain) case study. Eng. Geol. 2015, 198, 40-52.

89. Bozzano, F.; Esposito, C.; Franchi, S.; Mazzanti, P.; Perissin, D.; Rocca, A.; Romano, E. Understanding the subsidence process of a quaternary plain by combining geological and hydrogeological modelling with satellite InSAR data: The Acque Albule Plain case study. Remote Sens. Environ. 2015, 168, 219-238. [CrossRef]

90. Tortorici, L. Dati sulla neotettonica del bacino del fiume Crati (Cosenza). P.F. Geodin., Contrib. Realizz. Carta Neotettonica d'Italia 1979, 251, 341-350.

(C) 2015 by the authors; licensee MDPI, Basel, Switzerland. This article is an open access article distributed under the terms and conditions of the Creative Commons by Attribution (CC-BY) license (http://creativecommons.org/licenses/by/4.0/). 